\title{
Introduction to plant mutation breeding: Different approaches and mutagenic agents
}

\author{
A. C. Udage* \\ Received: 30 $0^{\text {th }}$ November 2020 / Accepted: $30^{\text {th }}$ July 2021
}

\begin{abstract}
Purpose: Plant breeding plays a significantly important role in ensuring global food security. Among several methods of plant breeding, mutation breeding has shown remarkable success in crop improvement at a much faster rate than traditional breeding. The present study was carried out to review the different approaches and mutagenic agents of plant mutation breeding.
\end{abstract}

Research Method: The review focused on both conventional and novel techniques of mutation breeding. To prepare a comprehensive article, the author reviewed selected available published information on experimental mutagenesis running back to the 20th century.

Findings: In nature, mutations happen at a much slower rate hindering the scientists' efforts of crop improvement. On the contrary, mutagens have provided the solution to a slow mutation rate by inducing mutations at much faster rates. Recent advances in science have opened up new paths of mutation breeding approaches. These approaches accompanied by state-of-the-art biotechnology has provided more effective, efficient, and robust results. For further development of mutation breeding, certain rules and regulations enacted worldwide must be addressed once more.

Originality/Value: The study provides a comprehensive review on current knowledge of different mutation breeding approaches and mutagenic agents.

Keywords: biological mutagen, biotechnology, chemical mutagens, mutation breeding, physical mutagens, plant breeding

\section{INTRODUCTION}

Plant breeding is an important aspect of agriculture. The major aim of plant breeding is to ensure future global food security. Breeding enables scientists to develop new plant varieties with improved characteristics such as climate resilience, yield, maturation time, and pest and disease resistance. There are many techniques for breeding plants; mutation breeding is one such technique applied for crop plant improvement.

Plant mutation breeding is neither a novel topic nor a novel technique. Since the early $20^{\text {th }}$ century, mutation breeding has been applied to both plants and animals. Subjecting animals to mutations are considered unethical and illegal, while plant mutation breeding has been accepted as a legit technique of increasing the genetic diversity of plants; more importantly, commercially grown crops. Unlike traditional breeding approaches, mutation breeding is more effective and less time-consuming. As science advances, mutation breeding approaches have developed significantly over the past few decades.

Most approaches to mutation breeding rely on mutagenic agents, which are responsible for the creation of mutations in plant genetic material. These mutagenic agents have been

\footnotetext{
Department of Export Agriculture, Uva Wellassa University of Sri Lanka, Passara Road, Badulla, 90000.

ashanranga@gmail.com
}

https://orcid.org/0000-0002-2614-4761 
in use for many decades now and proven to be an integral part of plant mutation breeding as it creates mutation at a much faster rate than a spontaneous mutation processes.

This review aims to address different approaches, different mutagenic agents, and to interpret how mutation breeding has been affected by novel biotechnological advances.

\section{MUTATION}

Mutation can be defined as a change in the genetic material at a particular locus in an organism (Macdonald, 2004). Mutations were originally defined by De Vries (1901, 1903, and 1905) as a sudden heritable change in the genetic material not caused by recombination or segregation (Lamo et al., 2017). Initially, De Vries used the word 'sudden' because it differentiates subtle changes that happen, which can be explained by the normal process of recombination, but with modern techniques, it is identified that mutations create changes, especially at the genotypic level which leads to subtle changes in phenotypes which may not be apparent suddenly. Hence, the word sudden was omitted from the definition (Shu et al., 2012). Mutations play an important role in evolution as the changes in genetic material inherited by the organisms lead to phenotypic innovations (Wagner, 2012).

\section{MUTAGENESIS}

Mutagenesis is simply defined as the formation of genetic mutations. Errors in DNA repair cause mutagenesis in nature. Exposure to genotoxic substances: chemicals or other substances that damage cellular DNA can lead to mutations in living organisms (Theodorakis, 2008). Mutagenesis can also be generated through experiments (experimental mutagenesis) using different methods. Physical and chemical methods of mutagenesis are commonly used in mutation breeding programs (Shu et al., 2012).

\section{MUTANT}

Mutant is the result of mutagenesis. A Mutant is an individual with a single mutation or multiple mutations in its genome, that may be revealed by molecular means or phenotyping (Shu,
Forster and Nakagawa, 2012).

\section{MUTATION BREEDING OF PLANTS}

Spontaneous mutations are the only source of new genetic variation that was known to mankind for the trait improvement of plants and animals, especially for agriculture purposes, until scientists discovered ionizing radiation, which is capable of modifying the genetic makeup of organisms. Soon after this discovery, ionizing radiation became the foundation of mutation breeding (Shu, Forster and Nakagawa, 2012).

The term mutation breeding was first used by Freisleben and Lein (1944). They used this term to refer to mutant lines that were intentionally induced and developed for crop improvement. In the current scenario, mutation breeding has become popular among the breeders for developing elite breeding lines and cultivated varieties while keeping its quality characteristics (Pathirana, 2011). Mutation breeding is an important part of the genetic improvement of crops and it has been an important component for assuring global food security and nutrition. By the year 2050, the world's human population is estimated to be 9-11 billion, hence the genetic improvement of crops plays a major role in ensuring future food security (Fróna et al., 2019).

Crop improvement programmes through induced mutations were initiated about nine decades ago, immediately after the discovery of mutagenic effects of X-rays on Drosophila by Muller in 1927 (Jankowicz-Cieslak et al., 2016; Kharkwal et al., 2004), and barley and maize by Stadler in 1928 (Lundqvist, 2014). In the 1950s and 60s, few countries such as the United States of America and Japan started using mutation breeding to improve crops. More than 3220 mutant varieties of crop plants have been developed up to now (Bado et al., 2015). Most of these mutant varieties are developed using physical mutagens such as gamma ray and X-ray. Among these mutant varieties, nearly $80 \%$ are seed propagated. According to Food and Agriculture Organization (FAO), nearly half of these mutant varieties are cereals that are cultivated around the world. Through 
mutation breeding, a wide range of traits have been improved such as yield, maturation time, quality, and tolerance to biotic and abiotic stresses (Jankowicz-Cieslak et al., 2016; Kharkwal et al., 2004).

Heritable variations in crops are an essential requirement of the genetic improvement of crops (Govindaraj et al., 2015). When these variations do not occur sufficiently in nature, they can be induced using a random or targeted process. Physical and chemical mutagens are commonly used to induce random genetic variations in crops. The response of the genetic variation in crops varies with mutagen type and dosage. (Jankowicz-Cieslak et al., 2016).

Mutation breeding consists of three major steps; (i) mutation induction, (ii) screening for promising mutant candidates, and (iii) mutant testing (mutant verification) and official release.

The first step, mutation induction is done by exposing the plant propagules to a physical, chemical or biological mutagen (Suprasanna et al., 2015). The second step, mutant screening is the process of selecting desired individuals from a large population of treated mutants. In this process, consideration should be given not to select 'Putative mutants', which means they are not true mutants, i.e., there could be a selected mutant individual who shows resistance to a disease, but in reality, the individual is not infected by the disease due to the absence of the pathogen (Shu et al., 2012).

Mutant confirmation or mutant verification is the process carried out to determine whether the selected individual is a true mutant or a false mutant. This can be done by re-evaluating putative mutants under replicated and thorough conditions, using a larger sample size (Shu et al., 2012). Screening of mutant variants and selection of the desired mutants happen based on their phenotypic characteristics. Compared with genotypic selection, phenotypic selection is more labour intensive and specialized (Jankowicz-Cieslak et al., 2016).

During the mutation breeding process, seeds directly exposed to mutagen are known as the M0 generation which on germination produces M1 plants (Forster et al., 2012). Self-fertilization of the M1 generation crops produces the progeny known as M2 generation (Lightner and Caspar, 1998). Figure 1 explains the basic process in a mutation breeding programme.

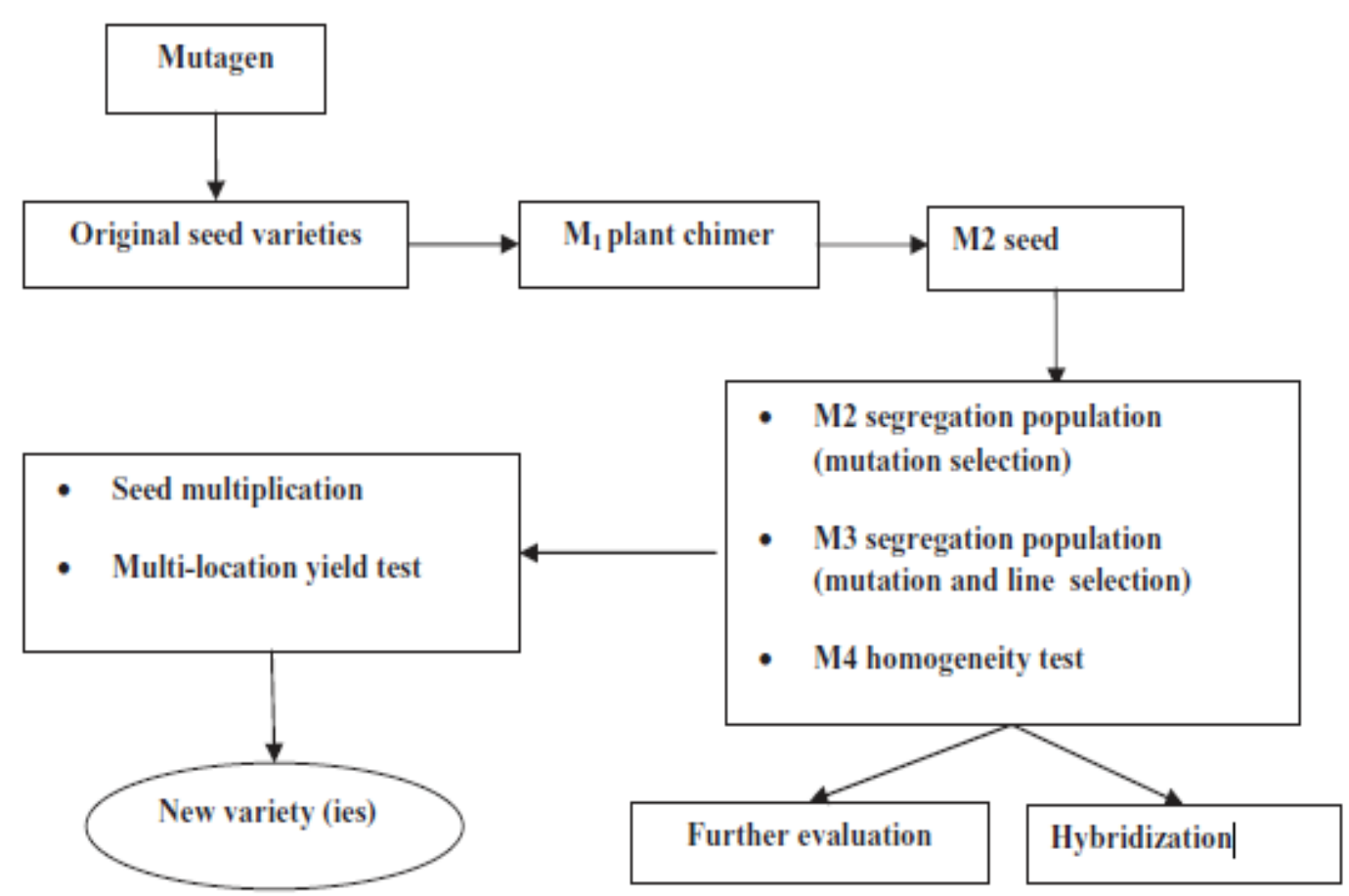

Figure 1. Process of Mutation Breeding

Reference - Oladosu et al. (2016) 


\section{EXPERIMENTAL MUTAGENESIS}

Using mutagenesis at experimental level is known as experimental mutagenesis. There are three types of experimental mutagenesis: Induced mutagenesis, insertional mutagenesis, and site-directed mutagenesis (Shu, Forster and Nakagawa, 2012). Mutagenesis can be achieved by physical agents such as ionising radiation; chemical agents such as alkylating agents, and biological agents such as transposons, retrotransposons, and Insertion Sequence (IS) elements (Serrat et al., 2014). Among these three methods, mutagenesis through physical or chemical agents is mostly preferred. (Shu, Forster and Nakagawa, 2012).

\subsection{Induced Mutagenesis}

Both random mutagenesis and targeted mutagenesis are part of induced mutagenesis (Shu, Forster and Nakagawa, 2012). Induced mutagenesis has been used widely in plant breeding since its discovery in the 1920s (Mba et al., 2010). Both physical and chemical mutagens have been used in induced mutagenesis. This experimental mutagenesis type has shown great success in developing new crop varieties, especially ornamental crops (Datta, 2014).

\subsection{Random Mutagenesis}

Also referred to as non-targeted mutagenesis (Shu, Forster and Nakagawa, 2012), random mutagenesis uses chemical and physical mutagens to produce mutants entirely random (Wei et al., 2013). Random mutagenesis has been used frequently for breeding. At least 2543 plant varieties in 175 plant species have been developed using random mutagenesis. However, the formation of multiple and unspecific mutations has limited its applications in plant breeding. Random mutagenesis is also a very time-consuming method (Araki and Ishii, 2015; Jung et al., 2018) hence, scientists have focused on new mutation breeding approaches.

\subsubsection{Role of plant biotechnologies in mutation breeding}

Biotechnological advances have opened new paths in plant mutation breeding. These new paths play an important role in the enhancement of mutation breeding approaches. Molecular marker technologies and plant breeding tools such as the doubled haploid technique are such paths used in novel mutation breeding programmes (IAEA, no date; Kharkwal, 2012).

\subsection{Targeted Mutagenesis}

Targeted mutagenesis incorporates novel biotechnological approaches to breed new mutant crops by either utilizing natural or induced mutations. Through targeted mutagenesis, the development of new crop varieties may be more practical since New Breeding Techniques (NBT) such as transgenic technologies have to cope with regulatory challenges (Holme et al., 2019; Wilde et al., 2012). Targeted mutagenesis also provides the added advantage of economic feasibility in trait development than the transgenic approach. The use of genomics in targeted mutagenesis reduces the time duration of breeding programmes significantly, which is a major bottleneck of traditional plant breeding programmes (Wilde et al., 2012). Genomic technologies such as Next Generation Sequencing (NGS) are used in targeted mutagenesis. Genomic approaches like Targeting Induced Local Lesions in Genomes (TILLING) and Eco TILLING have enabled screening of mutants in a population, more efficiently, (M. Perez-de-Castro et al., 2012) without the need for phenotypic screening. Further, genetic screening can identify heterozygous recessive traits, which cannot be identified by phenotypic screening (Wilde et $a l .$, 2012).

With the development of molecular biological techniques such as TILLING, direction of mutation breeding has taken a new path. TILLING allows rapid identification of mutations in genes of interest (Comai and Henikoff, 2006), which provides a better focused application of mutation breeding. Novel technologies like TILLING will improve the accuracy, efficiency, and effectiveness of mutation breeding. In addition to novel techniques like TILLING, development of plant tissue culture techniques has also assisted mutation breeding by shortening the time required for generation of mutant lines. These new techniques are environmentally friendly, 
cost effective and robust.

\subsection{Site-Directed Mutagenesis (SDM)}

Site-directed mutagenesis is one of the recent molecular crop improvement tools, which provides researchers with new techniques to alter the DNA sequence at a precise location (Gurushidze et al., 2016). Mutations through SDM can be performed in vitro or in vivo, allowing researchers to alter plant DNA at a single site or multiple sites. There are three methods of SDM in use: PCR-based, Nucleus based, and vector-based (Bezie et al., 2020).

Genome editing, a revolutionizing technique capable of precisely engineering mutation in the genome, is also used for SDM; for instance, Transcription Activator-Like Effector Nuclease (TALEN), Zinc Finger Nuclease (ZFN), and Clustered Regularly Interspaced Short Palindrome Repeats (CRISPR). ZFN is a primitive genome editing technology that is used less frequently now (Chaudhary, Deshmukh and Sonah, 2019). Apart from ZFN, TALEN was the most preferred genome editing technology used in many organisms including plants (Malzahn, Lowder and Qi, 2017). However, advent of the CRISPR/Cas9 system made it the most preferred choice, since it has been identified as the most efficient and easy to apply technique for genome editing (Jung et al., 2018). Although genome editing techniques are efficient in plant breeding, they are still challenged by regulations enacted for Genetically Modified Organisms (GMOs). Therefore, genome editing requires new global policies and regulations for its better advancement in the future (Araki and Ishii, 2015). Some scientists refer to SDM as the 'ultimate mutation breeding technology' (Saika et al., 2011), and this will possibly be the future of mutation breeding.

\subsection{Insertional Mutagenesis}

DNA insertion, either by genetic transformation and insertion of Transfer DNA (T-DNA) or activation of transposon elements, is referred to as insertional mutagenesis (Shu, Forster and Nakagawa, 2012). It is an important genetic tool for gene discovery using T-DNA, retrotransposons, activator/dissociation (Ac/Ds) insertions, and transposons (Ram et al., 2019). Insertional mutagenesis allows scientists to observe and understand many aspects of gene and chromosome behaviour (Sangwan et al., 2012).

\section{FACTORS AFFECTING MUTAGENIC EFFECT}

Plant genera, species, and to certain extent genotypes and varieties have a different response to mutagens. Apart from these factors, environmental factors such as oxygen concentration, water content, temperature, and storage conditions also influence the mutagenic effect (Kodym et al., 2012).

\section{MUTAGENS}

Mutagens are different forms of biological, chemical, and physical (radiation) agents that can cause irreversible and heritable changes in DNA (Schrader, 2003). Mutagens are of utmost importance for inducing mutations of plants, hence the selection of a proper mutagen is significantly important in mutation breeding as different mutagens have different mutagenic properties (Ukai, 2006). There are mainly two types of mutagens: Physical and chemical mutagens, which are illustrated in figure 2 .

\subsection{Physical Mutagens}

Physical mutagens are more advantageous than chemical mutagens since physical mutagens do not require washing off or treating of mutagens after use, and physical mutagens do not form waste (Shah Jehan Khan et al., 2000). Six types of physical mutagens have been mostly used to induce plant mutations: X-ray, gamma-ray, beta particles, fast neutrons, slow neutrons, and ultraviolet rays (Smith, 1958). These physical mutagens are categorized into two groups: ionizing radiations (e.g. X-rays, gamma rays, neutrons, alpha and beta particles) and Non-ionising radiations (e.g. ultraviolet rays). Among these, gamma rays are the most used irradiation ray with a percentage of $64 \%$ (Jain, 2005, 2010; Rédei, 2008). After gamma radiation, X-rays are the second most used irradiation ray (Beyaz and Yildiz, 2017). 


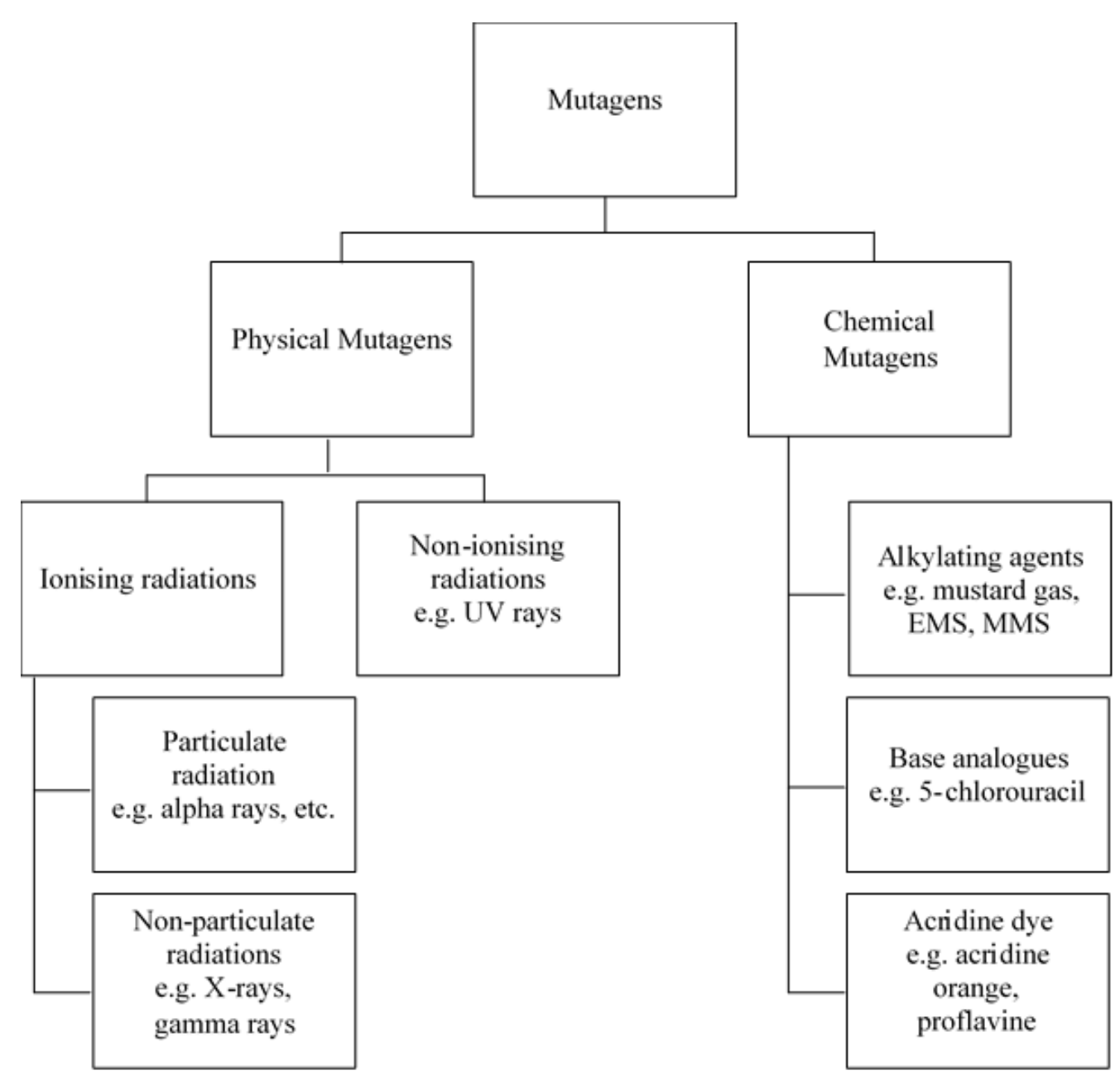

Figure 2. Common mutagens used in plant mutation induction

Reference - (M.M. Spencer-Lopes et al., 2018)

The first record of the use of physical mutagens runs back to the 1920s when scientists used radium on fruit fly and discovered its mutagenic effects (Kharkwal et al., 2004). More than 70\% of mutant varieties developed so far have been done using physical mutagens (Oladosu et al., 2016), since the discovery of hereditary effects of ionizing radiation by Muller and Stadler (Brunner, 1995). In 1927 Muller used X-ray on fruit fly and proved the mutation effects of X-ray. In 1928, Lewis John Stadler published three papers on the genetic effects of X-rays in maize and barley (Rhoades, 1957). Since these two discoveries, the use of physical mutagens for mutation breeding became prominent.

In recent times, ion beam radiation has become an effective and unique mutagen. Scientists have started experimenting more with other types of mutagenic radiation, without limiting to gamma rays. Recent use of fast neutrons to induce large deletions of genetic material is one such example for the use of other types of physical mutagens (International Atomic Energy Agency, 2021).

\subsubsection{Gamma rays:}

Since the 1950s, gamma irradiation has become the most popular physical mutagen. The reason for its prevalent use is its wide availability and flexibility in using for different purposes such as mutation breeding, food irradiation, and medical uses (Mba and Shu, 2011). Gamma rays have the shortest wavelength of all the physical mutagens and therefore, possess more energy than other physical mutagens (IAEA, 2004). Gamma rays have different sources 
for commercial production. Examples of such sources are radioisotopes of cobalt-60 $\left({ }^{60} \mathrm{Co}\right)$ and caesium-137 $\left({ }^{137} \mathrm{Cs}\right)$. Potassium-40 is a naturally occurring isotope that emits gamma rays that are found in the environment (Mba and Shu, 2012).${ }^{60} \mathrm{Co}$ and ${ }^{137} \mathrm{Cs}$ have different advantages and disadvantages when it is used as the source of gamma rays; ${ }^{137} \mathrm{Cs}$ has a longer half-life so it decays relatively slower than ${ }^{60} \mathrm{Co} ;{ }^{60} \mathrm{Co}$ has a half-life of 5.3 years whereas ${ }^{137} \mathrm{Cs}$ has a half-life of 30 years; On the other hand, ${ }^{137} \mathrm{Cs}$ should be exposed 4 times more to take the same dose effect of ${ }^{60} \mathrm{Co}$ (Mba and Shu, 2012).

\subsubsection{X-ray:}

In 1895, Wilhelm Conrad Roentgen discovered $\mathrm{X}$-ray. Since then this has been used vastly for clinical diagnosis thus, the number of researches done on the effect of X-ray in living organisms is numerous (Shull and Mitchell, 1933). High doses of X-rays are capable of causing mutations in plants, so scientists have been using this in mutation breeding programmes. $\mathrm{X}$-rays are known to originate from electrons and these electrons are electrically accelerated in a high vacuum and then directed to a target, e.g. a tungsten, gold, or molybdenum barrier to produce the radiation. For mutation induction in crops, X-rays with shorter wavelengths are preferred as they have higher penetration capability (M M Spencer-Lopes et al., 2018).

\subsubsection{Ultraviolet ( $U V)$ ray:}

In 1934 Altenberg first discovered the mutagenic effect of ultraviolet (UV) radiation (Altenburg, 1934). Since then, many types of researches have been carried out to assess the effect of UV radiation on crop plants. UV radiation is a component of sunlight and is the largest natural source of UV radiation. In the electromagnetic spectrum, UV radiation sits between X-ray and visible light, where it has a longer wavelength than X-ray, but a shorter wavelength than visible light. Depending on the wavelength of UV radiation, it is divided into three different ranges: UV-A, UV-B, and UVC. UV-C has the highest energy and is mostly affected by the ozone layer in the stratosphere. UV radiation has limited tissue penetration, thus its uses are limited for certain applications. However, UV radiation has become a great mutagen for mutation breeding in tissue culture (Castronuovo et al., 2014; Olawuyi, Bello and Abioye, 2016; M M Spencer-Lopes et al., 2018).

\subsubsection{Neutrons:}

Neutrons are found inside the atomic nucleus and are stable only inside it. The separation of neutrons from their nucleus will trigger releasing of various kinetic energies. These neutrons are categorized as slow (thermal) neutrons, intermediate neutrons and fast neutrons, according to the energy released (M M Spencer-Lopes et al., 2018). In the 1960s and 1970s neutrons have been used for mutagenesis. Fast neutron irradiation is a unique mutagenesis approach among other induced mutagenesis methods as fast neutrons are capable of deleting a few to several million DNA bases, and also results in rearrangement of chromosomes. Although this has been proven to be a good mutagen, its use has been limited due to a lack of dosimetry techniques (Kharkwal, 2012; Kumawat et al., 2019).

\subsubsection{Alpha particles:}

Alpha particles, consist of two protons and two neutrons, are emitted from radioactive atoms such as Radium and Plutonium. Unlike gamma or X-rays, these particles have a mass, thus considered as particles (Peirce, Weiner and Vesilind, 1998). However, the energy produced by alpha particles is insufficient for mutation induction in plants (van Harten, 1998).

\subsubsection{Beta particles:}

Just like alpha particles, beta particles also have a mass. Beta particles are emitted from radioactive isotopes such as phosphorus-32 and sulfur-35 are capable of producing mutations in plants. The penetration ability of these particles is less than that of X-ray and gamma-ray, but the problem of low penetration can be overcome by injecting these particles directly into the plant cells. Difficulties in the calculation of internal beta particle dose required to induce mutations have limited its use in mutation breeding (M M 
Spencer-Lopes et al., 2018).

\subsubsection{Ion beams:}

Over the past 30 years, Ion beam irradiation and ion beam implantation have gained popularity (Wang et al., 2010). Ion beams are capable of depositing high energy on a target, densely and locally. As a result, a higher mutation rate and wider novel mutation spectrum can be observed in mutants subjected to ion beam irradiation (Yamaguchi et al., 2009; Wang et al., 2010).

\subsubsection{Cosmic rays:}

Another new mutagenesis method that has been studied by scientists is sending planting materials to space to induce mutations. In space, plant materials are exposed to mutagens such as cosmic radiation (Kharkwal, 2012). These cosmic radiations can generate mutations in planting materials sent to space.

\subsubsection{Laser beams:}

Higher doses of laser beams can influence changes in the genetic material of plants. Therefore, scientists have started to experiment on laser beam irradiation, as a mutagen in mutation breeding of crops (Rybiński, 2000).

\subsection{Chemical Mutagens}

Mutation induction using chemicals was tried by many scientists for decades in the past century. The first convincing result of mutagenesis using chemicals was recorded in 1939 when Thom and Steinberger induced mutations in Aspergillus using nitrous acid. In 1946, Auerbach and Robson discovered that mustard gas has clear mutagenic effects. Chemical mutagens are highly capable of inducing true gene mutations, but still, the question remained whether the chemical mutagens are capable of inducing mutations in the same frequency as physical mutagens. This question was answered by Auerbach and Robson (1946) through their experiments and found that chemical mutagens are just as effective as physical mutagens. Since the discovery of the chemical mutagens, 100 s of chemical mutagens belonging to several groups have been identified: Alkylating agents, nitroso compounds, base analogues, azide, acridine dyes, etc.(Kharkwal, 2012; M M SpencerLopes et al., 2018).

Chemical mutagens have the major problem of residual formation. These chemical residues can be carcinogenic and cause health problems to human beings. Therefore, even with the promising results of chemical plant mutagens, researchers have looked for alternatives such as physical and biological mutagens as those mutagens do not create any residues after the treatment.

\subsubsection{Alkylating agents:}

Alkylating agents are being used as plant chemical mutagens for many years as they are the most successful chemical mutagen for creating new plant mutants. Many alkylating agents can be used in induced mutagenesis; Ethylenimine (EI), Ethyl methanesulfonate (EMS), methyl methanesulfonate (MMS), and Mustard gas are four such commonly used alkylating agents (Fujimoto and Yamagata, 1982). There are three functional types of alkylating agents: mono-, bi- or poly-functional types. Among these, polyfunctional and bifunctional alkylating agents are capable of cross-linking with DNA which leads to subsequent DNA degradation (Watson, 1964). Alkylating agents are effective and relatively easy to handle during experiments. Ease of detoxification before disposal of remnants is one major advantage of these chemicals (M M Spencer-Lopes et al., 2018).

\subsubsection{Sodium azide:}

Sodium azide $\left(\mathrm{NaN}_{3}\right)$ has several industrial uses such as bactericide, pesticide, and is also known to be highly mutagenic to plants and animals (Gruszka, Szarejko and Maluszynski, 2012). Apart from alkylating agents, sodium azide is also a commonly used very powerful toxic chemical mutagen in crop plants (Srivastava et al., 2011). Mutagenicity of sodium azide is highly influenced by $\mathrm{pH}$. This chemical interferes with cellular respiration and aerobic metabolism. In living cells, it is metabolized to a powerful chemical mutagen in many, but not all, plant species (Gruszka, Szarejko and Maluszynski, 2012). 
Table 1: Commonly used physical mutagens, its sources, characteristics, and hazards

\begin{tabular}{|c|c|c|c|c|}
\hline Mutagen & Source & Characteristics & Hazard & Reference \\
\hline X-rays & X-ray machine & $\begin{array}{l}\text { Electromagnetic radiation; } \\
\text { penetrates tissues from a } \\
\text { few millimetres to many } \\
\text { centimetres }\end{array}$ & $\begin{array}{l}\text { Dangerous, } \\
\text { penetrating }\end{array}$ & $\begin{array}{l}\text { Oladosu et } \\
\text { al. }(2016)\end{array}$ \\
\hline Gamma rays & $\begin{array}{l}\text { Radioisotopes and } \\
\text { nuclear reaction }\end{array}$ & $\begin{array}{l}\text { Electromagnetic radiation } \\
\text { produced by radioisotopes } \\
\text { and nuclear reactors; very } \\
\text { penetrating into tissues; } \\
\text { sources are }{ }^{60} \mathrm{Co} \text { (Cobalt-60) } \\
\text { and }{ }^{137} \mathrm{Cs} \text { (Caesium-137) }\end{array}$ & $\begin{array}{l}\text { Dangerous, } \\
\text { very } \\
\text { penetrating }\end{array}$ & $\begin{array}{l}\text { Oladosu et } \\
\text { al. }(2016)\end{array}$ \\
\hline Neutrons & $\begin{array}{l}\text { Californium-252 } \\
\left({ }^{252} \mathrm{Cf}\right)\end{array}$ & & & \\
\hline $\begin{array}{l}\text { Nuclear } \\
\text { reactors or } \\
\text { accelerators }\end{array}$ & $\begin{array}{l}\text { There are different } \\
\text { types (fast, slow, } \\
\text { thermal); produced } \\
\text { in nuclear reactors; } \\
\text { uncharged } \\
\text { particles; penetrate } \\
\text { tissues to many } \\
\text { centimetres; source } \\
\text { is }{ }^{235} \mathrm{U}\end{array}$ & Very hazardous & $\begin{array}{l}\text { Oladosu et } \\
\text { al. (2016) }\end{array}$ & \\
\hline Beta particles & $\begin{array}{l}\text { Radioactive } \\
\text { isotopes or } \\
\text { accelerators }\end{array}$ & $\begin{array}{l}\text { Produced in particle } \\
\text { accelerators or from } \\
\text { radioisotopes; are } \\
\text { electrons; ionize; shallowly } \\
\text { penetrating; sources include } \\
{ }^{32} \mathrm{P} \text { and }{ }^{14} \mathrm{C}\end{array}$ & $\begin{array}{c}\text { May be } \\
\text { dangerous }\end{array}$ & $\begin{array}{l}\text { Oladosu et } \\
\text { al. }(2016)\end{array}$ \\
\hline $\begin{array}{l}\text { Alpha } \\
\text { particles }\end{array}$ & Radioisotopes & $\begin{array}{c}\text { Derived from radioisotopes; } \\
\text { a helium nucleus capable } \\
\text { of heavy ionization; very } \\
\text { shallowly penetrating }\end{array}$ & $\begin{array}{c}\text { Very } \\
\text { dangerous }\end{array}$ & $\begin{array}{l}\text { Oladosu et al. } \\
\text { (2016) }\end{array}$ \\
\hline Protons & $\begin{array}{l}\text { Nuclear reactors or } \\
\text { accelerators }\end{array}$ & $\begin{array}{l}\text { Produced in nuclear reactors } \\
\text { and accelerators; derived } \\
\text { from hydrogen nucleus; } \\
\text { penetrate tissues up to } \\
\text { several centimetres } \\
\end{array}$ & $\begin{array}{c}\text { Very } \\
\text { dangerous }\end{array}$ & $\begin{array}{l}\text { Oladosu et } \\
\text { al. }(2016)\end{array}$ \\
\hline Ion beam & $\begin{array}{c}\text { Particle } \\
\text { accelerators }\end{array}$ & $\begin{array}{l}\text { Produced positively charged } \\
\text { ions are accelerated at a high } \\
\text { speed (around } 20 \%-80 \% \text { of } \\
\text { the speed of light) deposit } \\
\text { high energy on a target }\end{array}$ & Dangerous & $\begin{array}{l}\text { Oladosu et } \\
\text { al. (2016) }\end{array}$ \\
\hline
\end{tabular}




\subsubsection{Base analogues:}

Base analogues closely resemble DNA bases, and are capable of substituting normal bases in nucleic acid. These substitutions can change the DNA replication and transcription of genes. Examples for base analogues include 5-chlorouracil, 5-bromouracil, 2-aminopurine, and acycloguanosine (Bhagavan and Ha, 2015). Powerful Physical agents like gamma-rays and chemical agents like alkylating agents cause both beneficial and deteriorative mutations in plants but, base analogues are more advantageous, as point mutations in the genome of plants are possible (Fukui, 1985).

\subsubsection{Acridine Dyes:}

Acridine dyes are another group of chemical mutagens. Along with chemicals such as ethidium bromide and 4', 6-diamidino-2phenylindole (DAPI), acridine are considered as intercalating agents, which bind between adjacent base pairs of dsDNA. More often than not, these intercalating agents are used as fluorescent markers for DNA visualization (Hashemi Shabestari et al., 2017). Apart from its use as a fluorescent marker, Acridine dyes are capable of stretching the DNA strand, thereby allowing the deletion or addition of nucleotide bases (Kumar and Gorham, 1975). Acridine orange is one example of mutagenic acridine dye (Arshad et al., 2006).

\subsection{Biological Mutagens}

DNA Transposons, retrotransposon, and Insertion Sequence (IS) elements are considered biological mutagens. These are known as transposable elements in molecular biology and are divided into two major classes; Class I and Class II, based on their mechanism of transposition (Bourque et al., 2018).

Researches done on biological plant mutagens are at a minimal level currently. However, with the advancement of science and technology, new researches on biological plant mutagens will move forward. New biotechnological approaches and molecular biological techniques such as transposon technology will aid the development of biological mutagens.
Technologies such as the CRISPR-Cas9 system have the potential of becoming a great tool in plant mutation breeding as they have the ability to modify a target DNA with great accuracy (Cai et al., 2018).

\subsubsection{DNA transposons:}

DNA Transposons, also known as Class II elements, are mobilized via a DNA intermediate from one genomic location to another genomic location, thus referred to as 'jumping' genes as well. Transposons cause insertions, deletions, and other chromosomal mutations (Krishnan and Damaraju, 2019), therefore, has the potential of becoming a good mutagenic agent for plant mutation breeding.

\subsubsection{Retrotransposons:}

Retrotransposons, also called Class I transposable elements, are found in all eukaryotes, but not in prokaryotes (Bourque et al., 2018). Retrotransposons mobilize via an RNA intermediate and integrate into new sites of the host genome through cDNA, which is created through reverse transcription of the RNA (Qi and Sandmeyer, 2012). Retrotransposons are very important for the gene regulation of eukaryotes, therefore, can be used as a regulator of gene expression in plant breeding (Elbarbary, Lucas and Maquat, 2016).

\subsubsection{Insertion-Sequence (IS) elements:}

IS elements are segments of bacterial DNA that have the ability to move within or between genomes (Griffiths et al., 2000). These are small pieces of DNA, hence considered as the simplest type of transposable element (Chandler and Siguier, 2013). IS insertion into a genome can cause genomic instability resulting in mutations that can be used in plant mutation breeding (Williams, 2016). 
Table 2: Commonly used chemical mutagens, examples, and mode of action

\begin{tabular}{|c|c|c|c|}
\hline Mutagen group & Example & Mode of action & References \\
\hline $\begin{array}{l}\text { Alkylating } \\
\text { agents }\end{array}$ & $\begin{array}{l}\text { 1-methyl-1-nitrosourea (MNU) } \\
\text { 1-ethyl-1-nitrosourea (ENU) } \\
\text { methyl methanesulphonate } \\
\text { (MMS) } \\
\text { ethyl methanesulphonate (EMS) } \\
\text { dimethyl sulphate (DMS) } \\
\text { diethyl sulphate (DES) } \\
\text { 1-methyl-2-nitro-1- } \\
\text { nitrosoguanidine (MNNG) } \\
\text { 1-ethyl-2-nitro-1- } \\
\text { nitrosoguanidine (ENNG) }\end{array}$ & $\begin{array}{l}\text { React with bases and add } \\
\text { methyl or ethyl groups and, } \\
\text { depending on the affected } \\
\text { atom, the alkylated base may } \\
\text { then degrade to yield an abasic } \\
\text { site, which is mutagenic and } \\
\text { recombinogenic or mispair to } \\
\text { result in mutations upon DNA } \\
\text { replication. }\end{array}$ & $\begin{array}{l}\text { Oladosu et al. } \\
\text { (2016) }\end{array}$ \\
\hline Azide & Sodium azide & Same as alkylating agents. & $\begin{array}{l}\text { Oladosu et al. } \\
\text { (2016) }\end{array}$ \\
\hline Hydroxylamine & Hydroxylamine & Same as alkylating agents. & $\begin{array}{l}\text { Oladosu et al. } \\
\text { (2016) }\end{array}$ \\
\hline Hydroxylamine & Hydroxylamine & Same as alkylating agents. & $\begin{array}{l}\text { Oladosu et al. } \\
\text { (2016) }\end{array}$ \\
\hline Antibiotics & $\begin{array}{l}\text { Actinomycin D } \\
\text { mitomycin C } \\
\text { azaserine; streptonigrin }\end{array}$ & $\begin{array}{l}\text { Chromosomal aberrations also } \\
\text { reported to cause cytoplasmic } \\
\text { male sterility. }\end{array}$ & $\begin{array}{l}\text { Oladosu et al. } \\
(2016)\end{array}$ \\
\hline Nitrous acid & Nitrous acid & $\begin{array}{l}\text { Acts through deamination, } \\
\text { the replacement of cytosine } \\
\text { by uracil, which can pair with } \\
\text { adenine and thus through } \\
\text { subsequent cycles of replication } \\
\text { lead to transitions. }\end{array}$ & $\begin{array}{l}\text { Oladosu et al. } \\
\text { (2016) }\end{array}$ \\
\hline Acridines & Acridine orange & $\begin{array}{l}\text { Intercalate between DNA bases } \\
\text { thereby causing a distortion } \\
\text { of the DNA double helix } \\
\text { and the DNA polymerase, in } \\
\text { turn, recognizes this stretch } \\
\text { as an additional base and } \\
\text { inserts an extra base opposite } \\
\text { this stretched (intercalated) } \\
\text { molecule. This results in } \\
\text { frameshifts, i.e. an alteration of } \\
\text { the reading frame. }\end{array}$ & $\begin{array}{l}\text { Oladosu et al. } \\
\text { (2016) }\end{array}$ \\
\hline Base analogues & $\begin{array}{l}\text { 5-bromouracil (5-BU) } \\
\text { Maleic hydrazide } \\
\text { 5-bromodeoxyuridine } \\
\text { 2-aminopurine (2AP) }\end{array}$ & $\begin{array}{l}\text { Incorporate into DNA in place } \\
\text { of the normal bases during } \\
\text { DNA replication thereby } \\
\text { causing transitions (purine } \\
\text { to purine or pyrimidine } \\
\text { to pyrimidine); and } \\
\text { tautomerization (existing in two } \\
\text { forms which interconvert into } \\
\text { each other, e.g. guanine can } \\
\text { exist in keto or enol forms). }\end{array}$ & $\begin{array}{l}\text { Oladosu et al. } \\
(2016)\end{array}$ \\
\hline
\end{tabular}




\section{CONCLUSIONS}

Mutation breeding has come a long way, since its first experiment in the 1920s. Advancements in science have given new approaches to mutation breeding and improved its efficiency and robustness. However, to ensure the food security of the future world, these breeding approaches need to be further developed while adopting new policies and regulations to assist new breeding techniques. Primitive mutation breeding approaches such as random mutagenesis, which are time-consuming and creating imprecise mutations, should be given less priority. Scientists should promptly address the regulatory issues related to new breeding approaches such as site-directed and insertional mutagenesis. These new breeding approaches will be able to reduce most of the issues related to crop plant breeding and food security.

Even though mutation breeding has developed immensely since its beginning and was able to overcome many barriers which stopped it from becoming the most preferred plant breeding method, there is still certain regulatory uncertainty around mutation breeding. However, with the development of novel techniques and improvement of precision of mutation breeding techniques, the uncertainty of these regulatory systems is now challenged (Lassoued et al., 2018). Hopefully, in near future it will be accepted as a safe and sound method of plant breeding worldwide, which will increase the breeding of new plant varieties to cater for the food demand of the growing human population in the world.
Physical and chemical mutagens have been an integral part of mutation breeding. Even though many experiments are done on these two mutagenic agents, there is still space for progress. More experiments on physical mutagens such as ion beams and cosmic radiation should be carried out as these mutagenic agents can provide new mutation spectrums and higher mutation rates.

While physical and chemical mutagenic agents play a major role in plant mutation breeding, more thought should be given to the biological mutagenic agents as well. Biological mutagenic agents have a great potential for mutagenesis and with new molecular biology techniques, many of the challenges, i.e., regulatory challenges, associated with biological mutagenic agents can be resolved.

The effort exerted by the scientists on further development of mutation breeding with correct approaches will permit mankind to achieve the major goal of plant breeding, which will help global food security at large.

\section{Acknowledgements:}

I am grateful to G.Y.A.D.D. Perera and T.T.D Dharmarathana of Department of Agriculture, Faculty of Animal Science and Agriculture, Uva Wellassa University for extending their support for this review.

\section{Conflict of Interest:}

There is no conflict of interest.

\section{REFERENCES}

Altenburg, E. (1934). The Artificial production of mutations by ultra-violet light. The American Naturalist, 68(719), pp. 491-507. DOI: https://doi.org/10.1086/280570

Araki, M. and Ishii, T. (2015). Towards social acceptance of plant breeding by genome editing. Trends in Plant Science, 20(3), pp. 145-149. DOI: https://doi.org/https://doi.org/10.1016/j. tplants.2015.01.010

Arshad, R., Farooq, S., Iqbal, N. and Ali, S. S. (2006). Mutagenic effect of acridine orange on the expression of penicillin G acylase and beta-lactamase in Escherichia coli. Letters in Applied Microbiology, 42(2), pp. 94-101. DOI: https://doi.org/10.1111/j.1472-765X.2005.01819.x 
Bado, S., Forster, B. P., Nielen, S., Ali, A. M., Lagoda, P. J. L., Till, B. J. and Laimer, M. (2015). Plant mutation breeding: Current progress and future assessment. In Plant Breeding Reviews. 39, pp. 23-88. John Wiley and Sons, Inc. DOI: https://doi.org/10.1002/9781119107743.ch2

Beyaz, R. and Yildiz, M. (2017). The use of gamma irradiation in plant mutation breeding. In Plant Engineering. InTech. DOI: https://doi.org/10.5772/intechopen.69974

Bezie, Y., Tilahun, T., Atnaf, M. and Taye, M. (2020). The potential applications of site-directed mutagenesis for crop improvement: A review. BioRxiv, 2020.10.01.321984. DOI: https://doi. org/10.1101/2020.10.01.321984

Bhagavan, N. V. and Ha, C.E. (2015). Chapter 21 - structure and properties of DNA. (Second E. Ha (eds.); pp. 381-400). Academic Press. DOI: https://doi.org/https://doi.org/10.1016/B978$0-12-416687-5.00021-\mathrm{X}$

Bourque, G., Burns, K. H., Gehring, M., Gorbunova, V., Seluanov, A., Hammell, M., Imbeault, M., Izsvák, Z., Levin, H. L., Macfarlan, T. S., Mager, D. L. and Feschotte, C. (2018). Ten things you should know about transposable elements. Genome Biology, 19(1), 199. DOI: https://doi. org/10.1186/s13059-018-1577-z

Brunner, H. (1995). Radiation induced mutations for plant selection. Applied Radiation and Isotopes, 46(6-7), pp. 589-594. DOI: https://doi.org/10.1016/0969-8043(95)00096-8

Cai, Y., Chen, L., Liu, X., Guo, C., Sun, S., Wu, C., Jiang, B., Han, T.and Hou, W. (2018). CRISPR/ Cas9-mediated targeted mutagenesis of GmFT2a delays flowering time in soya bean. Plant Biotechnology Journal, 16(1), pp. 176-185. DOI: https://doi.org/10.1111/PBI.12758/FULL

Castronuovo, D., Tataranni, G., Lovelli, S., Candido, V., Sofo, A. and Scopa, A. (2014). UV-C irradiation effects on young tomato plants: Preliminary results. Pakistan Journal of Botany, 46, pp: 945-949.

Chandler, M. and Siguier, P. (2013). Insertion Sequences. (Second E. Hughes (eds.); pp. 86-94). Academic Press. DOI: https://doi.org/https://doi.org/10.1016/B978-0-12-374984-0.00799-3

Chaudhary, J., Deshmukh, R., and Sonah, H. (2019). Mutagenesis approaches and their role in crop improvement. Plants, 8(11), 467. DOI: https://doi.org/10.3390/plants 8110467

Comai, L. and Henikoff, S. (2006) 'TILLING: practical single-nucleotide mutation discovery', The Plant journal: for cell and molecular biology, 45(4), pp. 684-694. DOI: 10.1111/J.1365313X.2006.02670. X.

Datta, S. K. (2014). 5. Induced mutagenesis: basic knowledge for technological success. In Mutagenesis: exploring genetic diversity of crops (pp. 97-140). Wageningen Academic Publishers. https://doi.org/10.3920/978-90-8686-796-7_5

Elbarbary, R. A., Lucas, B. A. and Maquat, L. E. (2016). Retrotransposons as regulators of gene expression. In Science (Vol. 351, Issue 6274, p. aac7247). American Association for the Advancement of Science. DOI: https://doi.org/10.1126/science.aac7247

Fróna, D., Szenderák, J. and Harangi-Rákos, M. (2019). The challenge of feeding the world. 
Fujimoto, M. and Yamagata, H. (1982). Studies on the utility of artificial mutations in plant breeding: XIII. mutagenicity of several alkylating agents in rice. Japanese Journal of Breeding, 32(1), pp. 17-25. DOI: https://doi.org/10.1270/jsbbs1951.32.17

Fukui, K. (1985). Mutagenic effects of DNA base analogues on agronomic characters of rice (Oryza sativa L.). Jarq-Japan Agricultural Research Quarterly, 19(3), pp. 153-158.

Govindaraj, M., Vetriventhan, M. and Srinivasan, M. (2015). Importance of genetic diversity assessment in crop plants and its recent advances: An overview of its analytical perspectives. Genetics Research International, 2015. DOI: https://doi.org/10.1155/2015/431487

Griffiths, A. J., Miller, J. H., Suzuki, D. T., Lewontin, R. C. and Gelbart, W. M. (2000). Bacterial insertion sequences. In An Introduction to Genetic Analysis (7th edition). W. H. Freeman. https://www.ncbi.nlm.nih.gov/books/NBK21779/

Gruszka, D., Szarejko, I., and Maluszynski, M. (2012). Sodium azide as a mutagen (pp. 159-166). DOI: https://doi.org/10.13140/2.1.2105.8560

Gurushidze, M., Hiekel, S., Otto, I., Hensel, G. and Kumlehn, J. (2016). Site-directed mutagenesis in barley by expression of TALE nuclease in embryogenic pollen. In J. Jankowicz-Cieslak, T. H. Tai, J. Kumlehn, and B. J. Till (Eds.), Biotechnologies for Plant Mutation Breeding: Protocols (pp. 1-340). Springer International Publishing. DOI: https://doi.org/10.1007/9783-319-45021-6

Hashemi Shabestari, M., Meijering, A. E. C., Roos, W. H., Wuite, G. J. L. and Peterman, E. J. G. (2017). Chapter four - recent advances in biological single-molecule applications of optical tweezers and fluorescence microscopy. In M. Spies and Y. R. B. T.-M. in E. Chemla (Eds.), Single-Molecule Enzymology: Nanomechanical Manipulation and Hybrid Methods (Vol. 582, pp. 85-119).Academic Press. DOI: https://doi.org/https://doi.org/10.1016/bs.mie.2016.09.047

Holme, I. B., Gregersen, P. L. and Brinch-Pedersen, H. (2019). Induced genetic variation in crop plants by random or targeted mutagenesis: convergence and differences. Frontiers in Plant Science, 10. DOI: https://doi.org/10.3389/fpls.2019.01468

International Atomic Energy Agency (2011). Mutation breeding. https:/www.iaea.org/topics/ mutation-breeding. 22.11.2020

International Atomic Energy Agency (2021) Mutation induction in plants | IAEA. Available at: https://www.iaea.org/topics/mutation-induction. 28.07.2021

International Atomic Energy Agency (2004). Radiation, people and the environment. https://www. iaea.org/sites/default/files/radiation0204.pdf. 22.11.2020

Jain, S. M. (2005). Major mutation-assisted plant breeding programs supported by FAO/IAEA. Plant Cell, Tissue and Organ Culture, 82(1), pp. 113-123. DOI: https://doi.org/10.1007/ s11240-004-7095-6

Jain, S. M. (2010). Mutagenesis in crop improvement under the climate change. Romanian Biotechnological Letters, 15(2), pp. 88-106. https://www.rombio.eu/rbl1vol15Supplement/12 
Jung, C., Capistrano-Gossmann, G., Braatz, J., Sashidhar, N. and Melzer, S. (2018). Recent developments in genome editing and applications in plant breeding. Plant Breeding, 137(1), pp. 1-9. DOI: https://doi.org/10.1111/pbr.12526

Kharkwal, M. C. (2012). A brief history of plant mutagenesis. In Plant Mutation Breeding and Biotechnology (pp. 21-30). CABI Publishing. DOI: https://doi. org/10.1079/9781780640853.0021

Kharkwal, M. C., Pandey, R. N., \& Pawar, S. E. (2004). Mutation Breeding for Crop Improvement. Jain H.K., Kharkwal M.C. (eds), Plant Breeding (pp. 601-645). Springer, Dordrecht. DOI: https://doi.org/10.1007/978-94-007-1040-5_26

Kodym, A., Afza, R., Forster, B., Ukaid, Y., Nakagawa, H. and Mba, C. (2012). Methodology for physical and chemical mutagenic treatments http:/www.fao.org/3/a-i2388e.pdf. In Plant Mutation Breeding and Biotechnology (pp. 169-180). DOI: http://dx.doi. org/10.1079/9781780640853.0135

Krishnan, P. and Damaraju, S. (2019). Chapter 13 - piRNAs in the pathophysiology of disease and potential clinical applications (B. B. T.-A.-D. N.-C. Rna. Mallick (ed.); pp. 335-356). Academic Press. DOI: https://doi.org/https://doi.org/10.1016/B978-0-12-815669-8.00013-0

Kumar, H. D. and Gorham, P. R. (1975). Effects of acridine dyes and other substances on growth, lysis and toxicity of anabaena flos-aquae NRC-44-1. Biochemie Und Physiologie Der Pflanzen, 167(6), pp. 473-487. DOI: https://doi.org/10.1016/s0015-3796(17)31305-7

Kumawat, S., Rana, N., Bansal, R., Vishwakarma, G., Mehetre, S. T., Das, B. K., Kumar, M., Kumar Yadav, S., Sonah, H., Sharma, T. R. and Deshmukh, R. (2019). Expanding avenue of fast neutron mediated mutagenesis for crop improvement. Plants (Basel, Switzerland), 8(6), pp. 164. DOI: https://doi.org/10.3390/plants 8060164

Lamo, K., Ji Bhat, D., Kour, K. and Singh Solanki, S. P. (2017). Mutation studies in fruit crops: A review. International Journal of Current Microbiology and Applied Sciences, 6(12), pp. 3620-3633. DOI: https://doi.org/10.20546/ijcmas.2017.612.418

Lassoued, R., Smyth, S. J., Phillips, P. W. B. and Hesseln, H. (2018). Regulatory Uncertainty Around New Breeding Techniques. Frontiers in Plant Science, 0, 1291. DOI: https://doi. org/10.3389/fpls.2018.01291

Lightner, J. and Caspar, T. (1998). Seed mutagenesis of Arabidopsis. In Arabidopsis Protocols (pp. 91-102). Humana Press. DOI: https://doi.org/10.1385/0-89603-391-0:91

Lundqvist, U. (2014). Scandinavian mutation research in barley - a historical review. Hereditas, 151(6), pp. 123-131. DOI: https://doi.org/10.1111/hrd2.00077

M. Perez-De-Castro, A., Vilanova, S., Canizares, J., Pascual, L., M. Blanca, J., J. Diez, M., Prohens, J. and Pico, B. (2012). Application of genomic tools in plant breeding. Current Genomics, 13(3), pp. 179-195. DOI: https://doi.org/10.2174/138920212800543084

Macdonald, B. A. (2004). Population genetics of plant pathogens. The Plant Health Instructor. DOI: https://doi.org/10.1094/phi-a-2004-0524-01 
Malzahn, A., Lowder, L. and Qi, Y. (2017). Plant genome editing with TALEN and CRISPR. In Cell and Bioscience (Vol. 7, Issue 1, pp. 1-18). BioMed Central Ltd. DOI: https://doi. org/10.1186/s13578-017-0148-4

Mba, C. and Shu, Q. Y. (2012). Gamma irradiation. In Q. Shu, B. P. Forster, and H. Nakagawa (Eds.), Plant Mutation Breeding and Biotechnology (pp. 91-98). CABI. DOI: https://doi. org/10.1079/9781780640853.0091

Mba, C., Afza, R., Bado, S. and Jain, S. M. (2010). Induced mutagenesis in plants using physical and chemical agents. In Plant Cell Culture: Essential Methods (pp. 111-130). John Wiley and Sons. DOI: https://doi.org/10.1002/9780470686522.ch7

Oladosu, Y., Rafii, M. Y., Abdullah, N., Hussin, G., Ramli, A., Rahim, H. A., Miah, G. and USMAN, M. (2016). Principle and application of plant mutagenesis in crop improvement: a review. Biotechnology and Biotechnological Equipment, 30(1), pp. 1-16. DOI: https://doi.org/10.10 80/13102818.2015.1087333

Olawuyi, O. J., Bello, B. and Abioye, A. (2016). Mutagenic effects of ultraviolet radiation on growth and agronomic characters in maize cultivars. Molecular Plant Breeding. DOI: https:// doi.org/10.5376/mpb.2016.07.0001

Pathirana, R. (2011). Plant mutation breeding in agriculture. CAB Reviews: Perspectives in Agriculture, Veterinary Science, Nutrition and Natural Resources, 6(32), 1-20. DOI: https:// doi.org/10.1079/PAVSNNR20116032

Peirce, J. J., Weiner, R. F. and Vesilind, P. A. (1998). Chapter 16 - radioactive waste (J. J. Peirce, R. F. Weiner, and P. A. B. T.-E. P. and C. (Fourth E. Vesilind (eds.); pp. 211-231). ButterworthHeinemann. DOI: https://doi.org/https://doi.org/10.1016/B978-075069899-3/50017-1

Qi, X. and Sandmeyer, S. (2012). Nonhomologous recombination: retrotransposons (W. J. Lennarz and M. D. B. T.-E. of B. C. (Second E. Lane (eds.); pp. 283-291). Academic Press. DOI: https://doi.org/https://doi.org/10.1016/B978-0-12-378630-2.00508-9

Ram, H., Soni, P., Salvi, P., Gandass, N., Sharma, A., Kaur, A. and Sharma, T. R. (2019). Insertional mutagenesis approaches and their use in rice for functional genomics. Plants, 8(9), pp. 310. DOI: https://doi.org/10.3390/plants8090310

Rédei, G. P. (2008). Physical mutagens. In Encyclopedia of Genetics, Genomics, Proteomics and Informatics (pp. 1493-1493). Springer Netherlands. DOI: https://doi.org/10.1007/978-14020-6754-9_12828

Rhoades, M. M. (1957). Lewis John Stadler - 1896-1954. National Academy of Sciences.

Rybiński, W. (2000). Influence of laser beams on the variability of traits in spring barley. International Agrophysics, 14, pp. 227-232.

Saika, H., Oikawa, A., Matsuda, F., Onodera, H., Saito, K. and Toki, S. (2011). Application of gene targeting to designed mutation breeding of high-tryptophan rice. Plant Physiology, 156(3), pp. 1269-1277. DOI: https://doi.org/10.1104/pp.111.175778

Sangwan, R., Ochatt, S., Nava-Saucedo, J.E. and Sangwan, B. (2012). T-DNA insertion 
mutagenesis. Plant Mutation Breeding and Biotechnology, pp. 489-506. DOI: http://dx.doi. org/10.1079/9781780640853.0489

Schrader, T. J. (2003). Mutagens (B. B. T.-E. of F. S. Caballero and N. (Second Edition) (eds.); pp. 4059-4067). Academic Press. DOI: https://doi.org/https://doi.org/10.1016/B0-12227055-X/00817-8

Serrat, X., Esteban, R., Guibourt, N., Moysset, L., Nogués, S. and Lalanne, E. (2014). EMS mutagenesis in mature seed-derived rice calli as a new method for rapidly obtaining TILLING mutant populations. Plant Methods, 10(1), pp. 5. DOI: https://doi.org/10.1186/1746-4811-105

Shah J. K., Hamid U. K., Rahim D. K., Malik M. I. and YUSUF Z. (2000). Development of sugarcane mutants through in vitro mutagenesis. Pakistan Journal of Biological Sciences, 3(7), pp. 1123-1125. DOI: https://doi.org/10.3923/pjbs.2000.1123.1125

Shu, Q. Y., Forster, B. P. and Nakagawa, H. (2012). Plant mutation breeding and biotechnology. In Plant Mutation Breeding and Biotechnology. CABI Publishing. DOI: https://doi. org/10.1079/9781780640853.0000

Shull, C. A. and Mitchell, J. W. (1933). Stimulative effects of x-rays on plant growth. Plant Physiology, 8(2), pp. 287-296. DOI: https://doi.org/10.1104/pp.8.2.287

Smith, H. H. (1958). Radiation in the production of useful mutations. Botanical Review, 24(1), pp. 1-24. http://www.jstor.org/stable/4353579

Spencer-Lopes, M. M., Jankuloski, L., Mukhtar Ali Ghanim, A., Matijevic, M. and Kodym, A. (2018). Physical mutagenesis. In M. M. Spencer-Lopes, B. P. Forster, and L. Jankuloski (Eds.), Manual on MUTATION BREEDING. Plant Breeding and Genetics Sub programme. Joint FAO/IAEA Division of Nuclear Techniques in Food and Agriculture.

Srivastava, P., Marker, S., Pandey, P. and Tiwari, D. K. (2011). Mutagenic effects of sodium azide on the growth and yield characteristics in wheat (Triticum aestivum L. em. Thell.). Asian Journal of Plant Sciences, 10(3), pp. 190-201. DOI: https://doi.org/10.3923/ajps.2011.190.201

Suprasanna, P., Mirajkar, S. J. and Bhagwat, S. G. (2015). Induced mutations and crop improvement. In Plant Biology and Biotechnology: Plant Diversity, Organization, Function and Improvement (Vol. 1, pp. 593-617). Springer India. DOI: https://doi.org/10.1007/978-81-322-2286-6_23

Theodorakis, C. W. (2008). Mutagenesis. In Encyclopedia of Ecology, Five-Volume Set (pp. 24752484). Elsevier Inc. DOI: https://doi.org/10.1016/B978-008045405-4.00408-0

Ukai, Y. (2006). Effectiveness and efficiency of mutagenic treatments. In Gamma Field Symposia. https://www.naro.affrc.go.jp/archive/nias/eng/gfs/pdf/045.PDF

Van Harten, A. M. (1998). Mutation breeding: theory and practical applications. Cambridge University Press. https://research.wur.nl/en/publications/mutation-breeding-theory-andpractical-applications

Wagner, A. (2012). The role of robustness in phenotypic adaptation and innovation. Proceedings of the Royal Society B: Biological Sciences, 279(1732), pp. 1249-1258. DOI: https://doi. 
org/10.1098/rspb.2011.2293

Wang, T. G., LI, X., Yang, T. and Wang, W. (2010). Ion beam bio-engineering and crop breeding. Advanced Materials Research, 108-111(1), pp. 536-542. DOI: https://doi.org/10.4028/www. scientific.net/AMR.108-111.536

Watson, W. A. F. (1964). Evidence of an essential difference between the genetical effects of monoand bi-functional alkylating agents. Zeitschrift Für Vererbungslehre, 95(4), pp. 374-378. DOI: https://doi.org/10.1007/BF01268670

Wei, F.J., Droc, G., Guiderdoni, E. and Hsing, Y. C. (2013). International consortium of rice mutagenesis: resources and beyond. Rice, 6(1), pp. 39. DOI: https://doi.org/10.1186/19398433-6-39

Wilde, H. D., Chen, Y., Jiang, P. and Bhattacharya, A. (2012). Targeted mutation breeding of horticultural plants. Emirates Journal of Food and Agriculture, 24(1), pp. 31-41. https://www. researchgate.net/publication/315657475_Targeted_mutation_breeding_of_horticultural_ plants

Williams, A. B. (2016). Chapter 5 - genome instability in bacteria: Causes and consequences (I. Kovalchuk and O. B. T.-G. S. Kovalchuk (eds.); pp. 69-85). Academic Press. DOI: https:// doi.org/https://doi.org/10.1016/B978-0-12-803309-8.00005-7

Yamaguchi, H., HASE, Y., Tanaka, A., Shikazono, N., Degi, K., Shimizu, A. and Morishita, T. (2009). Mutagenic effects of ion beam irradiation on rice. Breeding Science, 59(2), pp. 169177. DOI: https://doi.org/10.1270/jsbbs.59.169 